\title{
Evaluation of Antimicrobial Activity of Scallop Shell Powder Against Staphylococci Species and Gram Negative Bacteria Isolated From Patients Intensive Care Units
}

\author{
Nazmi Gultekin*1 and Emine Kucukates ${ }^{2}$ \\ ${ }^{1}$ Department of Cardiology, Turkey \\ ${ }^{2}$ Laboratory of Clinical Microbiology, Turkey
}

Received: 阱 January 18, 2019; Published: 制January 28, 2019

*Corresponding author: Nazmi Gultekin, Department of Cardiology, Turkey

\begin{abstract}
In the present study, we evaluated the bactericidal activity of scallop shell powder against methicillin resistant Staphylococci spp extendedspectrum beta-lactamase(ESBL) positive Escherichia coli and Klebsiella pneumoniae isolates obtained from hospitalized patients in the coronary and surgical intensive care units (ICUs).

Keywords: Intensive Care Unit; Staphylococci; E. Coli ;k. Pneumoniae; Scallop Shall Powder; Fungi

Abbreviations: HSSP: Heated scallop shell powder; ESBL: Extended Spectrum Beta Lactamase; ICUs: Intensive Care Units; Clinical; CLSI : Laboratory Standard Institute; SSP: Scallop Shell Powder; CNS: Coagulase Negative Staphylococci; ESBL: Extended Spectrum Beta Lactamase; MIC: Minimal Inhibitory Concentration
\end{abstract}

\section{Introduction}

Scallop shells are waste products of scallop harvesting in district of Korea and Japan. Large numbers of shells are heaped near the seaside, creating problems such as offensive odors and soil pollution from heavy metals contained in the viscera. Therefore, new applications for scallop shells need to be developed. Scallop shells contains calcium carbonate $\left(\mathrm{CaCO}_{3}\right)$ as the main component, when scallop shells are heated to $>700^{\circ} \mathrm{C}$ is converted to calcium oxide (CaO). Heated scallop shell powder (HSSP) exhibits strong antimicrobial activity to the vegetative bacteria, spores and fungi. $\mathrm{CaO}$ has been utilized mainly as an acidity regular and food additive [1-5] (Figure 1). In the present study, we evaluated the bactericidal activity of scallop shell powder against methicillin resistant Staphylococci spp extended-spectrum beta-lactamase (ESBL) positive Escherichia coli and Klebsiella pneumoniae isolates obtained from hospitalized patients in the coronary and surgical intensive care units (ICUs).

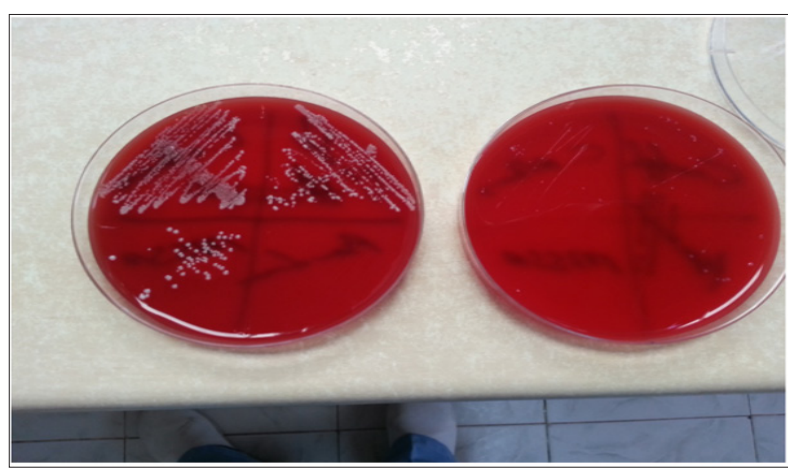

Figure 1: Antimicrobial Activity of Scallop Shell Powder against Staphylococci Species, Pseudomanas Aeruginosa, Gram Negative Bacteria and Candida Albicans Isolated from Patients Intensive Care Units. 


\section{Materials and Methods}

We investigated 50 methicillin resistant Staphylococci species [25 S. aureus and 25 coagulase negative staphylococci (CNS)], 30 E. coli and $20 \mathrm{~K}$. pneumoniae isolates by microdilution method. The microdilution method recommended by the Clinical and Laboratory Standard Institute (CLSI) for antibiotic susceptibility testing was modified and applied for scallop shell powder (SSP). We have obtained to scallop shell powder commercially. Scallop shell powder of the $1 \%$ solution was prepared and sterile saline $(0.85 \%)$ was used for preparing this disinfectant solution. Its $\mathrm{P}^{\mathrm{H}}$ level was close to neutral $\left(\mathrm{P}^{\mathrm{H}}=6.54\right)$ and low level of mineral content. After the disinfectant solution was freshly prepared, its $\mathrm{pH}$ measurement was made by a Selecta Digital $\mathrm{P}^{\mathrm{H}}$ meter at $25^{\circ} \mathrm{C}$ as a standard. Scallop shell powder solution $\mathrm{P}^{\mathrm{H}}$ was 9.14 .

All wells except the first wells of microplates containing 12 wells in one row were placed $100 \mu$ l Mueller Hinton Broth (MHB) (Oxoid, UK). $200 \mu \mathrm{l}$ was added from the substance solution to be tested in the first well of each well and transferred to the second well of $100 \mu \mathrm{l}$ from there and the process was continued until the well was pushed out $100 \mu \mathrm{l}$ from the $11^{\text {th }}$ well. So that serial dilutions were made at concentrations two fold dilutions for scallop shell powder. The suspension was prepared at a concentration of 0.5 McFarland in 24 hour bacterial cultures for the bacterial inoculum and diluted 10 times with sterile saline $(0.85 \%)$. We added to all wells except for $11^{\text {th }}$ well in the diluent series for each $5 \mu$ l of bacteria from these suspensions. In the $11^{\text {th }}$ well used as a control are only the MHB and scallop shell powder, and in the $12^{\text {th }}$ well only the MHB and bacteria were present. All wells except the first and $12^{\text {th }}$ wells of microplates containing 12 wells in one row were placed $100 \mu$ l. All microplates were incubated at $35^{\circ} \mathrm{C}$ for 24 hours. The highest concentration at which the bacterial reproduction is not observed (lowest concentration of solution) was detected. S. aureus ATCC 29213, E. coli ATCC 25922 and K. pneumoniae BCC 1395 were used as control strains.

\section{Results}

A total of 100 nosocomial isolates were obtained from intensive care units (ICUs) patients. The following isolates were found to be the most common: $30 \mathrm{E}$. coli ( 30\% ), 25 methicillin resistant S. aureus (25\%), 25 methicillin resistant coagulase negative staphylococci ( $25 \%$ ), and $20 \mathrm{~K}$. pneumoniae (20\%). All of E. coli and K. pneumonia strains were extended spectrum beta-lactamase (ESBL) positive. Scallop shell powder against methicillin resistant Staphylococci spp. was the most effective, followed by ESBL positive K. pneumoniae and E. coli, respectively (Table 1).

Table 1: No of strains at scallop shell powder concentation $\mu \mathrm{l} / \mathrm{ml}$.

\begin{tabular}{|c|c|c|c|c|c|c|}
\hline Microorganism & $1 / 4$ & $1 / 16$ & $1 / 32$ & $1 / 64$ & $1 / 128$ & $1 / 256$ \\
\hline S.aureus (25) & & & & 5 & 7 & 13 \\
\hline $\begin{array}{l}\text { Coagulase negative } \\
\text { staphylococci (25) }\end{array}$ & & & & 5 & 8 & 12 \\
\hline K.pneumoniae (20) & & & & 5 & 7 & 8 \\
\hline E.coli $(30)$ & & & 8 & 12 & 10 & \\
\hline TOTAL $\quad 100$ & & & & & & \\
\hline
\end{tabular}

\section{Discussion}

Scallop is one of the major marine products in Hokkaido, Japan. As a result, about 300.000 tons per year of scallop shells are generated as industrial waste in this region of Japan alone. The scallop shells contain $\mathrm{CaCO}_{3}$ (98-99\%) as the main component, and $1-2 \%$ organic compounds. Also, $\mathrm{CaCO}_{3}$ is a very cheap material. By heat treatment, $\mathrm{CaCO}_{3}$ is converted to $\mathrm{CaO}$ which exhibited strong antibacterial activity, a food supplement and an adsorbent of formaldehyde $[1-3,6,7]$. The authors have previously studied the activity of ceramic powders on the growth of bacteria and twenty six kinds of ceramic powders, such as metallic oxide and carbide, were investigated for their antibacterial effect and of these ten kinds of powders found to inhibit bacterial growth. $\mathrm{CaO}$, in particular, exhibited strong antibacterial and antifungal action against a broad range of microorganisms [8-11]. However, there have been a lot of studies on the bactericidal effect of heated scallop shell powders on foodborne pathogenic bacteria [1-7,11-21].

In some studies, the authors have reported protease activity of heated scallop shell powder and therefore, heated scallop shell powder has a useful ability in protecting skin [22-24]. Suggest that feeding scallop shell powder increases gene expression of
Uncoupling Protein 1 (UCP1) that may regulate energy metabolism in white adipose tissue, resulting in the observed reduction in weight of white adipose tissue of rats. They measured the changes in serum leptin level after feeding scallop shells to confirm the action of dietary scallop shells. Leptin is believed to regulate body weight homeostasis and energy balance. Also, there is deodorization effect of scallop shell powder and ability to reduce volatile organic compounds (VOC) investigated the effect of scallop shell powder on butanoic acid and acetic acid, substances that produce VOC [25]. Scallop shells alone and building materials (for wall construction) containing scallop shell powder removed these acids. Yoshida et al. [26] reported that heated scallop shells, which contain $\mathrm{CaO}$ as the main component, adsorbed chemicals such as formaldehyde, odiferous compounds, and VOCs.

Prevention of fungal contamination indoors and removal of VOCs by mixing antimicrobial substances into wall materials or paints may contribute to a safe living environment. With an aging society and an trend toward an increase in chemical allergies, many applications exist for heated shell powder Sawai et al. [1,2,9-15] investigated in the a lot of studies, scallop shell powder heated at $700^{\circ} \mathrm{C}$ or higher exhibited antibacterial activity against several foodborne pathogens, including S. aureus, E. coli 0157:H7, L.

Cite this article: Nazmi Gultekin, Emine Kucukates. Evaluation of Antimicrobial Activity of Scallop Shell Powder Against Staphylococci Species and Gram Negative Bacteria Isolated From Patients Intensive Care Units. Biomed J Sci \& Tech Res 13(4)-2019. BJSTR. MS.ID.002445. DOI: 10.26717/ BJSTR.2019.13.002445. 
monocytogenes, Bacillus subtilis and Salmonella typhimurium. They reported the bactericidal effect of scallop shell powder on foodborne pathogenic microorganisms. Bae et al. [3] found the $\mathrm{CaO}$ solutions should be used within 24 hour for the greatest bactericidal action against foodborne pathogenic bacteria. Cagri-Mehmetoglu [4] showed that L. monocytogenes or Salmonella enteritidis present on the surface of chicken wings could be decreased significantly by immersion of the wings in scallop shell powder. Jung et al. [16] investigated the bactercidal effect of $\mathrm{CaO}$ to Pseudomonas aeruginosa biofilms on quail eggshells and major egg contacting surfaces (stainless steel, plastic, and rubber). They reported that scallop shell powder was highly effective to reduce the number of bacteria and the amount of biofilm reduction on different surfaces and therefore, it can be used as an action bactericidal agent on $P$. aeruginosa biofilms in quail eggs and eggs contact surface material.

Asada et al. [18] evaluated the bactericidal effect of calcium oxide and calcined shell calcium to Legionella pneumophila in water samples taken from the cooling tower of a prefabricated houses. They obtained that calcium oxide and calcined shell calcium were effective to reduce bacteria numbers. They also have exhibited antimicrobial effect through heat treatment. Both of them were equally effect to L. pneumophila. Legionella species are common in the natural environments (i.e. soil, lakes, rivers). Since natural city water can pass to mains water, it can be used in artificial water systems; may settle and multiply in water tanks of buildings, airconditioner system cooling towers, stagnant areas of building water system, biofilm in piping. At present, chlorination, heating, ozone or UV light have been used in the disinfection of Legionella species.

Bodur et al. [5,6] conducted with scallop powder, it was reported that the L. monocytogenes, S. aureus and E. coli bacterial load was reduced. They indicated that bacteriostatic effect of calcium oxide results from the changes in $\mathrm{P}^{\mathrm{H}}$ level. Also, it is suggested that, in other mechanism, hydroxyl ions show a strong free radical effect and reacts with some biomolecules. Bacterial membrane functions such as the maintenance of cell integrity, substrate transport, the activities of the membrane-associated enzymes and are based on membrane fluidity. It is likely that the membrane fluidity will be affected by the temperature increase. When the temperature of the cells is above a critical level, a gel-liquid crystalline phase transition of the membrane phospholipids should occur. Therefore, membrane fluidity may affect the bactericidal action of the shell powder. The phase transition of the cell membrane induces a change in conformation of charged molecules, such as proteins on the surfaces of cells, which causes a variation in the interaction between the cells and shell powder. Also, the permeability of the membrane might vary due to changes in membrane fluidity. Although there is no study concerning S. aureus, it was considered that similar changes in the membrane might occur. An alkaline effect caused by the hydration of $\mathrm{CaO}$ is considered to be one of the primary mechanisms of bactericidal action in the shell powder slurry [1].

Watanabe el al. [27] investigated the antimicrobial activity of heated scallop shell nano-particles, prepared using a wet grinding mill, to vegetative bacteria and spores, and compared their effect with that of micro-particles. The median diameters of the nano-particles and micro-particles were approximately $20 \mathrm{~nm}$ and $30 \mu \mathrm{m}$, respectively. They showed the sporocidal activity of the nano-particles was also much higher than that of microparticles, with heated scallop shall nano-particles able to kill Bacillus subtilis spores. Jeong et al. [28] investigated in 50-90nm nano-particles of heated scallop shell and found the potential for further applications in cosmetic raw materials and drug delivery systems. Sawai et al. [29] prepared nano-sized of heated scallop shell powder (20-50 nm) and examined its sporocidal activity to Bacillus subtilis spores. They showed that the sporocidal action of the nanosized heated scallop shell powder increased significantly compared to that of heated scallop shell powder with a particle size of $30 \mu \mathrm{m}$. A a lot study are necessary for the effective use of nanosized heated scallop shell powder. Nosocomial infections constitute an important world-wide health problem with high morbidity and mortality rates as well as economic consequences. These infections become especially prominent in intensive care units, where the incidence is two to seven times greater than in the general inpatient population. Major risk factors for nosocomial infections are prolonged hospitalization, use of long term central venous catheter and urinary catheter, invasive device utilization, mechanic ventilation, parenteral nutrition, immunodeficiency, use of broad-spectrum antibiotic, decreased host defense, colonization and dialysis. The use of broad-spectrum antibiotics can lead to colonization with resistant Gram negative rods and consequently to serious infections.

Nosocomial infections are frequently associated with drug resistant microorganisms, including methicillin resistant $S$. aureus and extended spectrum beta-lactamase (ESBL) producing Gram negative bacteria, which can pose considerable thearapeutic problem. The advent of ESBL procedures has represented a great threat to the use of many classes of antibiotics, particularly cephalosporins [30]. In our study, the minimal inhibitory concentration (MIC) values were determinated as the lowest concentration of antimicrobial agent that completely inhibits growth of the microorganism and the antimicrobial activity was evaluated using microdilution method. Scallop shell powder was the most effective to methicillin resistant Staphylococci spp. ( $S$. aureus and coagulase negative staphylococci) and also, effective $K$. pneumoniae and E. coli (all of ESBL positive) isolated from patients coronary and surgical intensive care units. Alkaline effects caused by the hydration of calcium oxide are considered one of the primary mechanisms of the antimicrobial action of heated scallop shell powder [2].

We tought that considered to possess other antimicrobial mechanisms in additon to alkalinity. However, heated scallop shell powder were effective the other microorganisms obtained from intensive care units. We did not find a study on the effect of the strains obtained from the intensive care units of scallop shell powder in the literature. In our study, examined isolates were resistant bacteria and heated scallop shell was quite effective against these resistant bacteria. In conclusion, preventing nosocomial infection in the ICU is very important effective disinfection and reduce infection risk 
in this area. It is suggested that heated scallop shell powder can be used as a bio-disinfectant due to good antibacterial activity. Therefore, further research in this area is need for the effective use of scallop shell in nosocomial infections.

\section{Acknowledgment}

The authors thank Koksal Gultekin for research studies in the laboratory.

\section{References}

1. Sawai J, Shiga H, Kojima H (2001) Kinetic analysis of the bactericidal action of heated scallop-shell powder. Int J Food Microbiol 71: 211-228.

2. Sawai J (2011) Antimicrobial characteristics of heated scallop shell powder and its application. Biocontrol Sci 16(3): 95-102.

3. Bae DH, Yeon JH, Park SH, Lee DH, Ha SD (2006) Bactericidal effects of $\mathrm{CaO}$ (scallop-shell powder) on foodborne pathogenic bacteria. Arch Pharm Res 29(4): 298-301.

4. Cagri Mehmetoglu (2011) Inhibition of Listeria monocytogenes and Salmonella enteritidis on chicken wings using scallop-shell powder. Poult Sci 90(11): 2600-2605.

5. Bodur T, Yaldırak G, Kola O, Cagri Mehmetoglu A (2010) Inhibition of Listeria monocytogenes and Escherichia coli 0157:H7 on frankfurters using scallop-shell powder. J Food Safety 30(3): 740-752.

6. Bodur T, Cagri Mehemtoglu A (2012) Removel of Listeria monocytogenes, Staphylococcus aureus and Escherichia coli 0157:H7 biofilms on stainless steel using scallop shell powder. Food Cont 25: 1-9.

7. Bari ML, Inatsu Y, Kawasaki S, Nazuka E, Isshiki K (2002) Calcined calcium killing of Escherichia coli 0157:H7, Salmonella and Listeria monocytogenes onthe surface of tomatoes. J Food Prot 65(11): 17061711.

8. Okouchi S, Murata R, Sugita H, Moriyoshi T, Maeda N (1998) Calorimetric evaluation of the antimicrobial activities efficacy of calcined dolomite. J Antibact Antifung Agents 26: 109-114.

9. Sawai J, Igarashi H, Hashimoto A, Kokugan T, Shimizu M (1995) Effect of ceramic powder slurry on spores of Bacillus subtilis. J Chem Eng Jpnb 28(5): 556-561.

10. Sawai J, Igarashi H, Hashimoto A, Kokugan T, Shimizu M (1996) Effect of particle size and heating temperature of ceramic powders on bacterial activity of their slurry. J Chem Eng Jpn 29(2): 251-256.

11. Sawai J, Kojima H, Igarashi H, Hashimoto A, Shoji S, et al. (1997) Escherichia coli damage by ceramic powder slurries. J Chem Eng Jpn 30(6): 1034-1039.

12. Sawai J, Kojima H, Igarashi H, Hashimoto A, Shoji S, et al. (1999) Bactericidal action of calcium oxide powder. Trans Mater Res Soc Jpn 24: 667-70.

13. Sawai J, Miyoshi H, Kojima H (2003) Sporocidal kinetics of Bacillus subtilis spore by heated scallop shell powder. J Food Prot 66(8): 14821485.

14. Sawai J, Satoh M, Horikawa M, Shiga E, Kojima H (2001) Heated scallop shell powder slurry treatment of shredded cabbage. J Food Prot 64(10): 1579-1583.
15. Sawai J, Nagasawa K, Kikuchi M (2013) Ability of heated scallop-shell powder to disinfect Staphylococcus aureus biofilm. Food Sci Technol Res 19(4): 561-568.

16. Jung SJ, Park SY, Kim SE, Kang I, Park J, et al. (2017) Bactericidal effect of calcium oxide (scallop-shell powder) against Pseudomonas aeruginosa biofilm on quail egg shell, stainless steel, plastic and rubber. J Food Sci 82(7): 1682-1687.

17. Kubo M, Ohshima Y, Irie F, Kikuchi M, Sawai J (2013) Disinfection treatment of heated scallop-shell powder on biofilm of Escherichia coli ATTC 25922 surrogated for E. coli 0157:H7. J Biomater Nanobiotechnol 4(4): 10-9.

18. Asada T, Ornichi T, Kimura T, Okawa K (2001) Bactericidal effect of calcium on Legionella pneumophila. J Health Sci 47(4): 414-448.

19. Koga K, Tamura T, Ikemoto H (2008) Colorimetric evaluations of Bacillus subtilis vegetative and spore cells colonial growth and suppressive effects of sucrose monopalmitate. Biocontrol Sci 13: 111-1118.

20. Francissa L, Zhou B, Park H, Feng H (2011) The effect of calcined calcium and chlorine treatments on Escherichia coli 0157:H7 87-23 population reduction in radis sprouts. J Food Sci 76(6): 404-412.

21. Abadias M, Usall J, Anguera M, Solsona C, Viñas I (2008) Microbiological quality of fresh, minimally-processed fruit and vegetables, and sprouts from retail establishments. Int J Food Microbiol 123(1-2): 121-129.

22. Liu YC, Uchiyama K, Natsui N, Hasegawa Y (2002) In vitro activities of the components from scalp shells. Fish Sci 68: 1330-1366.

23. Fukuda M, Hasegawa Y (2014) Protease activity of a 90-kDa protein isolated from scallop shells. Turk J Fish Aquat Sci 14(1): 247-254.

24. Liu YC, Satoh K, Hasegawa Y (2006) Feeding scallop shell powder induces the expression of uncoupling protein 1 (UCP1) in white adipose tissue of rats. Biosci Biotechnol Biochem 70(11): 2733-2738.

25. Kishi M, Ogasawara T (2002) Purification of water quality in a pool on public facility. Memoirs of Hokkaido Institute of Technology 30: 137142.

26. Yoshida T, Koyama N, Okuda S, Sasaya K, Fukuhara C, etal. (2003) Reducing effect of scallop shell seramics on the concentration of formaldehyde in atmosphere. Bulletin of Research Institute for Interdisciplinary Science Hachinohe Institute of Technology 1: 113-1136.

27. Watanabe T, Fujimoto R, Sawai J, Kikuchi M, Yahata S, et al. (2014) Antibacterial characteristics of heated scallop-shell nano-particles. Biocontrol Sci 19(2): 93-97.

28. Jeong MS, Park JS, Song SH, Se Bok Jang AS (2007) Characterization of antibacterial nanoparticles from the scallop, Ptinopecten yessoensis. Biosci Biotechnol Biochem 71(9): 2242-2247.

29. Sawai J, Fijimoto R, Watanabe T, Kikuchi M, Yahata S, et al. (2010) Antimicrobial characteristics of nano-particle of heated scallop shell. The proceedings of $37^{\text {th }}$ Annual Meeting of the Society of Antibacterial and Antifungal Agents, Japan, 37, IPA-14.

30. Vincent JL (2003) Nosocomial infections in adult intensive care units. Lancet 361(9374): 2068-2077. 


\section{ISSN: 2574-1241}

DOI: $10.26717 / B J S T R .2019 .13 .002445$

Nazmi Gultekin. Biomed J Sci \& Tech Res

(c) (i) This work is licensed under Creative

Submission Link: https://biomedres.us/submit-manuscript.php

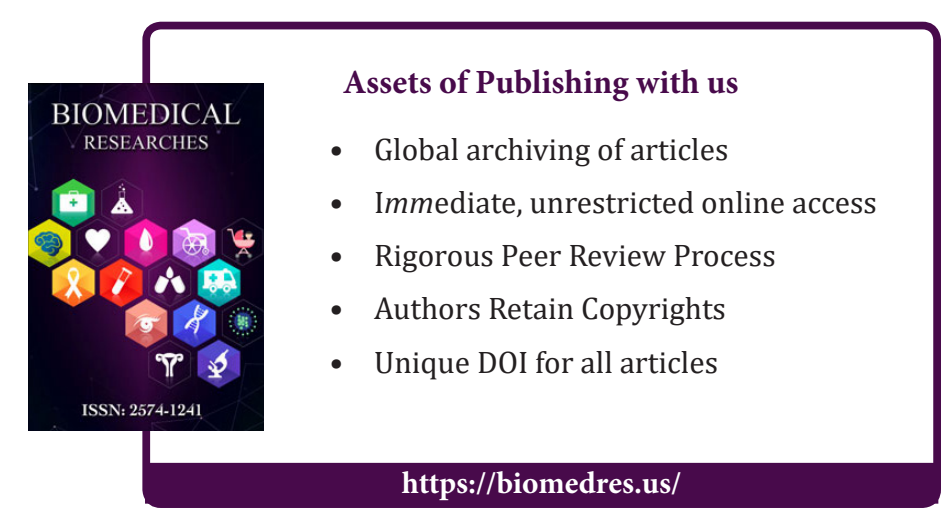

